\title{
A Production Function Explanation of Saudi Economic Growth 1984-2011
}

\author{
Mohammed Abdullah Aljebrin ${ }^{1}$ \\ ${ }^{1}$ College of Business Administration, Majmaah University, Saudi Arabia \\ Correspondence: Mohammed Abdullah Aljebrin, College of Business Administration, Majmaah University, PO \\ Box 11952, Majmaah, Saudi Arabia. E-mail: maljebrin@mu.edu.sa
}

Received: March 20, 2013

Accepted: April 2, 2013

Online Published: April 18, 2013

doi:10.5539/ijef.v5n5p97

URL: http://dx.doi.org/10.5539/ijef.v5n5p97

\begin{abstract}
This paper attempts at an explanation of Saudi economic growth along the lines proposed by the neo-classical growth theory. Production function estimates for gross domestic product is provided using Cobb-Douglas function. A wide range of econometric testing is employed. The functional form is estimated using a constant to express the technical progress. The result shows an elasticity of output with respect to capital and labor of about 0.67 and 0.57 respectively. Technical progress has positive contribution to growth rate of output of $8.67 \%$ a year. Therefore, it is a difficult task for the policy makers to determine the best policies for the enhancement of capital and labor on economic growth. The major policy implications and recommendations are that Saudi Arabia needs to improve the rate of return to education in order to raise the productivity of labor. That may be occurred by investing large amount of resources in increasing and improving educational attainment for men and women, and by increasing the training levels in industrial and services sectors.
\end{abstract}

Keywords: production function, Cobb-Douglas Production Function, FMOLS model, Saudi Arabia

\section{Introduction}

As global economic recovery lifted up oil prices in 2010, the Saudi economy recorded high growth and enlarged fiscal spending by the government boosted domestic demand and accelerated the growth in non-oil GDP. On the same line, the actual budget recorded a surplus of SAR 87.7 billion or 5.4 percent of GDP in 2010 against a deficit of SAR 86.6 billion or 6.2 percent of GDP in the previous year. On the other hand, the ratio of public debt to GDP declined from 16.1 percent in 2009 to 9.9 percent in 2010. The current account of the balance of payments recorded a surplus for the twelfth year consecutively amounting to SAR 250.3 billion or 14.9 percent of GDP in 2010 (Saudi Arabian Monetary Agency (SAMA, 2011).

Figures 1, 2 and 3 illustrate the developments of real GDP, real capital formation and total number of employees in Saudi Arabia during the period 1984-2011. The Figures indicate that there are similar directions among real GDP and Gross capital formation and a less degree of similarity with the number of employees.

This study aims at determining the contribution of capital and labor in Saudi economy by applying Cobb-Douglas Production Function in order to determine how the growth rate can be maximized.

Table 1 and Figure 2 illustrate the structure of gross capital formation, it indicates that non-oil private sector absorb the highest share in Saudi capital formation with a percentage reached $42.8 \%$ in 2011 . While the oil sector ranked second in terms of relative importance and finally the government sector. 


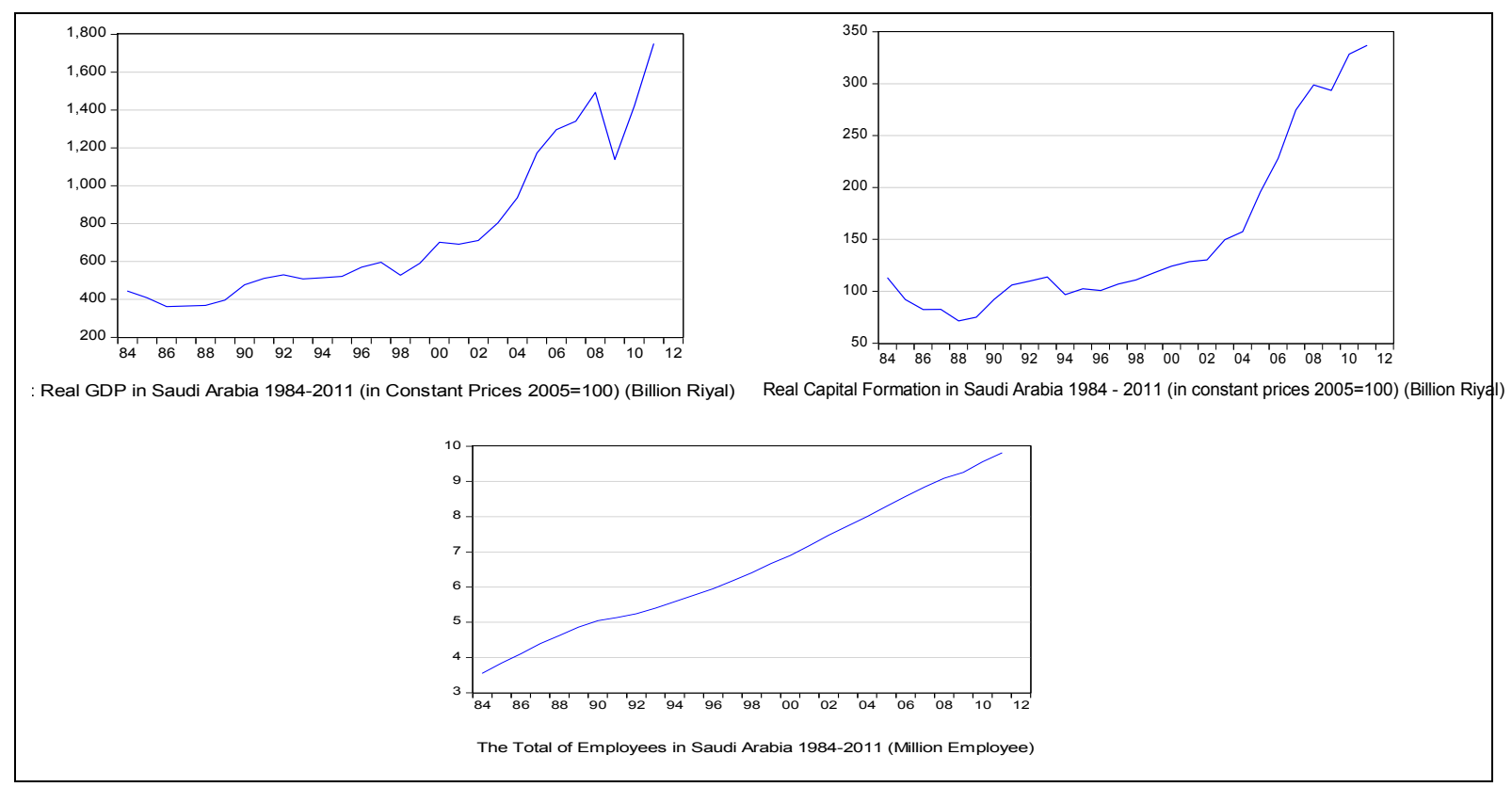

Figure 1. Real GDP, real capital formation and total number of employees in Saudi Arabia (1984-2011) Source: Table (A-1) in the appendix.

Table 1. Gross capital formation structure in Saudi Arabia 1984-2011 (constant prices 2005=100) (Billion Riyals)

\begin{tabular}{|c|c|c|c|c|c|}
\hline Year & Government Sector & Non-Oil Private Sector & Oil Sector & Change in Stock & Gross Fixed Capital Formation \\
\hline 1984 & 49.301 & 43.244 & 10.170 & 33.183 & 135.898 \\
\hline 1985 & 35.989 & 38.692 & 9.116 & -3.449 & 80.348 \\
\hline 1986 & 28.569 & 36.339 & 10.127 & -11.380 & 63.654 \\
\hline 1987 & 31.574 & 35.774 & 7.781 & -17.050 & 58.079 \\
\hline 1988 & 27.438 & 36.131 & 1.424 & 2.875 & 67.869 \\
\hline 1989 & 29.707 & 36.833 & 1.734 & 3.435 & 71.709 \\
\hline 1990 & 47.046 & 31.088 & 4.688 & -19.210 & 63.612 \\
\hline 1991 & 47.727 & 38.861 & 4.757 & -5.110 & 86.234 \\
\hline 1992 & 34.120 & 57.786 & 7.397 & 11.628 & 110.931 \\
\hline 1993 & 31.400 & 63.179 & 8.365 & 13.471 & 116.416 \\
\hline 1994 & 24.923 & 54.156 & 8.478 & 7.150 & 94.707 \\
\hline 1995 & 24.954 & 53.164 & 14.643 & 2.249 & 95.010 \\
\hline 1996 & 12.650 & 79.733 & 8.361 & 3.975 & 104.719 \\
\hline 1997 & 15.764 & 82.084 & 9.098 & 3.755 & 110.701 \\
\hline 1998 & 12.219 & 87.497 & 11.265 & 9.428 & 120.409 \\
\hline 1999 & 12.905 & 91.715 & 13.093 & 9.383 & 127.096 \\
\hline 2000 & 16.472 & 93.627 & 14.120 & 8.968 & 133.185 \\
\hline 2001 & 17.833 & 96.100 & 14.505 & 3.562 & 132.001 \\
\hline 2002 & 18.415 & 99.042 & 12.689 & 11.222 & 141.368 \\
\hline 2003 & 23.531 & 104.745 & 21.349 & 11.492 & 161.116 \\
\hline 2004 & 30.599 & 109.803 & 17.039 & 23.976 & 181.416 \\
\hline 2005 & 54.940 & 118.461 & 22.231 & 20.055 & 215.687 \\
\hline 2006 & 57.472 & 127.137 & 43.422 & 16.669 & 244.700 \\
\hline 2007 & 78.936 & 137.511 & 61.008 & 13.117 & 290.572 \\
\hline 2008 & 93.936 & 146.978 & 56.594 & 40.992 & 338.500 \\
\hline 2009 & 91.201 & 136.841 & 44.8 & 20.807 & 293.649 \\
\hline 2010 & 103.169 & 144.917 & 47.175 & 33.051 & 328.312 \\
\hline 2011 & 145.705 & 143.474 & 46.343 & 1.247 & 336.769 \\
\hline
\end{tabular}

Note: Saudi Arabian Monetary Agency (SAMA), Annual Report, No. 48. World Bank, World Bank Development Indicator. 


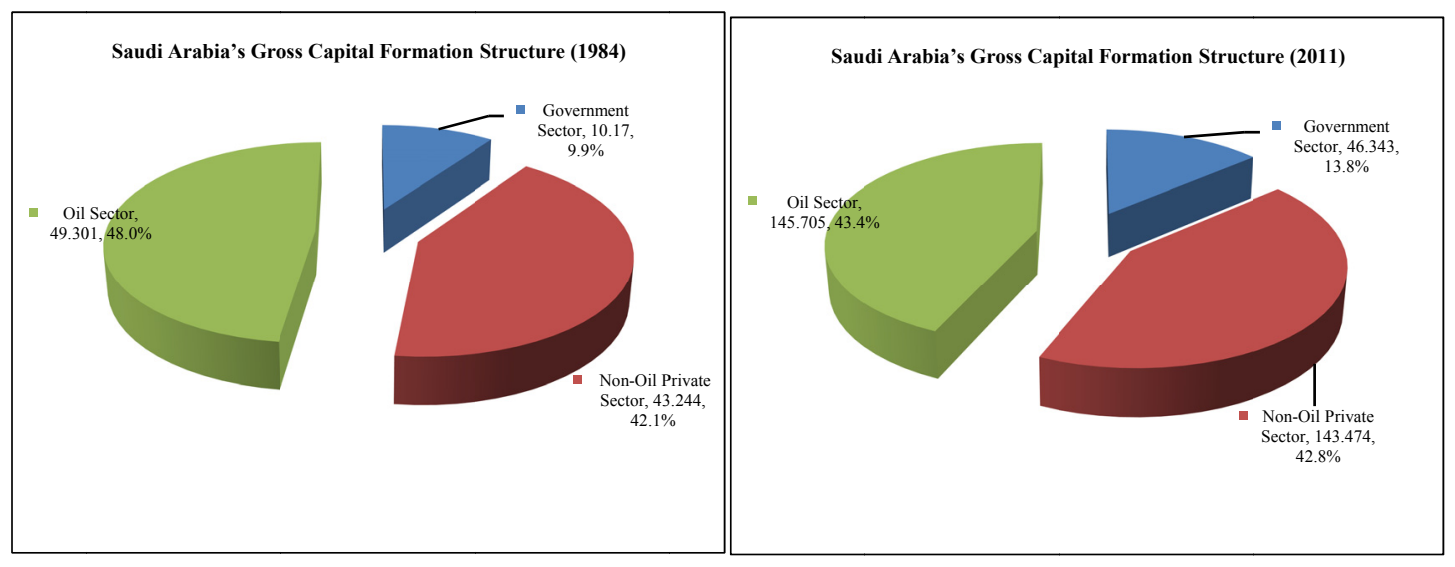

Figure 2. The structure of Gross Capital Formation in Saudi Arabia 1984-2011

Table 2 shows that the services sector is the most sectors that absorb labor in Saudi Arabia, as it accounted for three-quarters of employees during the period 1999-2009. While the industrial sector absorbed about fifth of employees, finally the agriculture sector absorbed only about $5 \%$ of total employment during the same period.

Table 2. Employment structure by economic activities in Saudi Arabia (\% of total employment)

\begin{tabular}{llll}
\hline Year & Agriculture (\%) & Industry (\%) & Services (\%) \\
\hline 1999 & 6.3 & 21 & 72.7 \\
2000 & 6.1 & 19.9 & 74 \\
2001 & 6.1 & 21.1 & 72.8 \\
2002 & 4.6 & 21 & 74.4 \\
2006 & 4 & 20.2 & 75.8 \\
2007 & 4.3 & 20.8 & 74.9 \\
2008 & 4.3 & 19.8 & 75.9 \\
2009 & 4.1 & 20.4 & 75.5 \\
\hline
\end{tabular}

Notes: Saudi Arabian Monetary Agency (SAMA), Annual Report, No. 48. World Bank, World Bank Development Indicator.

\section{Literature Review}

Cobb-Douglas Production Function is one of the most widely used production function in Economics and Management research (Douglas 1934 and 1948). This production function not only satisfies the basic economic law but also easy in its computation and interpretation of the estimated parameters. The objectives of applying Cobb- Douglas production function is to estimate the co-efficient of inputs, their marginal productivities, factor shares in total output and degree of returns to scale. It is based on unitary elasticity of substitution of inputs and this production function has been widely applied in empirical studies.

Given the Cobb-Douglass function components, for the capital factor $(\mathrm{K})$ we have used data of the gross capital formation, for labor (L) the number of employees. The data series is for the period 1984-2011, the value expressions for GDP and $\mathrm{K}$ are expressed in billions of riyal in constant prices $(2005=100)$. Labor is expressed in millions of workers employed.

In our analysis, we have assumed the general form of Cobb-Douglass production function:

$$
Y_{t}=A K_{t}^{\alpha} L_{t}^{\beta}
$$

Where:

$\mathrm{Y}_{\mathrm{t}}=$ gross domestic product for year $\mathrm{t}$

$\mathrm{K}_{\mathrm{t}}=$ fixed capital formation for year $\mathrm{t}$

$L_{t}=$ labor employed for year $t$;

$\mathrm{t}=$ time 
We also mention that $\mathrm{A}, \alpha, \beta$, shows the overall significance related to the function, namely " $\mathrm{A}$ " is the size factor reflecting overall productivity of production factors, " $\alpha$ " is the elasticity of output relative to the capital formation, and finally " $\beta$ " is the elasticity of output in relation to work. The factors that influence the productivity level are different and with different impact on the outcome.

If $\alpha+\beta>1$, it would imply that the output increase would be more than proportionate to the increase in inputs, if $\alpha+\beta<1$, it would imply that the output increase would be less than proportionate to the increase in inputs and if $\alpha+\beta=1$ the output would just increase proportionately to the rate of increase of inputs. Therefore there will be economies of scale, constant returns to scale or diseconomies of scale depending upon whether $\alpha+\beta$ is greater than 1 , equal to 1 , or less than 1 respectively.

\section{The Model and the Methods}

The logarithm of both sides of the above Cobb-Douglass production function was taken to convert the equation into linear form; its log transformation is specified below, which is to be estimated by Fully Modified Ordinary Least Squares (FMOLS) approach. FMOLS was originally designed first time by Philips and Hansen (1990) and Philips and Moon (1999) to provide optimal estimates of Co-integration regressions. This technique employs kernal estimators of the Nuisance parameters that affect the asymptotic distribution of the OLS estimator. In order to achieve asymptotic efficiency, this technique modifies least squares to account for serial correlation effects and test for the endogeneity in the regressors that result from the existence of a Co-integrating Relationships. The model that has been estimated is:

$$
\log (Y)=\log (A)+\alpha \log (K)+\beta \log (L)+\varepsilon
$$

The variable of "Y" has been expressed by the real Gross Domestic Product, while "K" has been be proxied by real gross capital formation and finally, labor force " $L$ " has been expressed by the number of employees and " $\varepsilon$ " is the error term.

\section{Data}

This study used the annual data from 1984 to 2008 for Saudi Arabia. All data in this study was obtained from Saudi Arabian Monetary Agency (SAMA) and World Bank Development Indicator, the data has been converted to real values (2005 constant prices) by using consumer price index $(2005=100)$. All these factors are illustrated at Table (A-1) in the appendix.

\section{Empirical Results}

\subsection{Unit Root and Cointegration Tests}

Augmented Dickey- Fuller unit root test is calculated for individual series to provide evidence as to whether the variables are stationary and integrated of the same order.

The results of Augmented Dickey-Fuller (ADF) test for each variable appear in Table 2. The lag parameter in the ADF test is selected by Akaike information criterion (AIC) to eliminate the serial correlation in residual (Akaike, 1973). As shown in Table 3, the null hypothesis of a unit root can't be rejected for all series. However, the unit root hypothesis is rejected for all variables in the first-differenced data. Therefore, we conclude that the series are integrated of order one.

Table 3. Unit root test

\begin{tabular}{lll}
\hline & & ADF \\
\hline $\log (\mathrm{Y})$ & Level & 0.916719 \\
& First Diff. & $-4.592865^{\mathrm{a}}$ \\
\hline $\log (\mathrm{K})$ & Level & 0.005893 \\
& First Diff. & $-3.164287^{\mathrm{b}}$ \\
\hline $\log (\mathrm{L})$ & Level & -0.674087 \\
& First Diff. & $-3.201651^{\mathrm{b}}$ \\
\hline
\end{tabular}

Notes: ADF-Dickey DA, Fuller WA., (1979) unit root test with the Ho: Variables are I (1); a, b and c indicate significance at the $1 \%, 5 \%$ and $10 \%$ levels, respectively.

The linear combination of the variables may however be stationary. This claim is being supported by the cointegrating relationships explored using 5\% critical value. The Johansen approach in Tables 4 and 5 under the trace and Maximal Eigenvalue statistics indicate only one cointegrating equation testifying to the long run 
relationship among the variables with $\mathrm{Y}$ as the dependent variable. The parameter instability approach in Table 5 further confirms this claim of long run relationship among the variables with probability value greater than 0.2 thereby accepting the null hypothesis of existence of cointegrating relationship.

Table 4. Cointegration test based on trace of the stochastic matrix

\begin{tabular}{lllll}
\hline Hypothesized No. of E(s) & Eigenvalue & Trace Statistic & 0.05 Critical Value & Prob.** \\
\hline None * & 0.997885 & 187.7262 & 29.79707 & 0.0001 \\
At most 1 & 0.420682 & 15.28659 & 15.49471 & 0.0537 \\
At most 2 & $4.65 \mathrm{E}-05$ & 0.001302 & 3.841466 & 0.9703 \\
\hline
\end{tabular}

Notes: Trace test indicates 1 cointegrating eqn(s) at the 0.05 level; * denotes rejection of the hypothesis at the 0.05 level; **MacKinnon-Haug-Michelis (1999) p-values.

Table 5. Cointegration test based on maximal eigenvalue of the stochastic matrix

\begin{tabular}{lllll}
\hline Hypothesized No. of E(s) & Eigenvalue & Max-Eigen Statistic & 0.05 Critical Value & Prob.** \\
\hline None * & 0.997885 & 172.4396 & 21.13162 & 0.0001 \\
At most $1 *$ & 0.420682 & 15.28529 & 14.26460 & 0.0344 \\
At most 2 & $4.65 \mathrm{E}-05$ & 0.001302 & 3.841466 & 0.9703 \\
\hline
\end{tabular}

Notes: Max-eigenvalue test indicates 2 cointegrating eqn(s) at the 0.05 level; * denotes rejection of the hypothesis at the 0.05 level; **MacKinnon-Haug-Michelis (1999) p-values.

Table 6. Cointegration result of Hansen parameter instability approach

\begin{tabular}{lllll}
\hline Lc statistic & Trends $(\mathrm{m})$ & Trends $(\mathrm{k})$ & Trends $(\mathrm{p} 2)$ & Prob.* \\
\hline 0.150597 & 2 & 0 & 0 & $>0.2$ \\
\hline
\end{tabular}

Notes: *Hansen (1992) Lc(m2=2, $\mathrm{k}=0) \mathrm{p}$-values, where $\mathrm{m} 2=\mathrm{m}-\mathrm{p} 2$ is the number of stochastic trends in the asymptotic distribution.

Since the two variables are cointegrated, they can be represented equivalently in terms of a long run FMOLS framework.

\subsection{Model Results}

In Table 7, we see the results of the long run FMOLS estimates for equation 3. The explanatory power is high $\left(\mathrm{R}^{2}=97.4\right)$. All the explanatory variables are significant at $1 \%$ level.

$$
\begin{gathered}
\log (Y)=2.16+0.67 \log (K)+0.57 \log (L)+\varepsilon \\
\widehat{\mathrm{A}}=\mathrm{e}^{2.16}=8.67
\end{gathered}
$$

Then,

$$
\mathrm{Y}_{\mathrm{t}}=8.67 \mathrm{~K}_{\mathrm{t}}^{0.67} \mathrm{~L}_{\mathrm{t}}^{0.57}
$$

According to above results, $A=8.67, \alpha=0.67, \beta=0.57$, provided that $\alpha+\beta>1$ and $\alpha, \beta>0$. We also saw that the influence of the capital on the production of GDP is much higher than in the case of labor. We therefore conclude that the national economy is one more capital-intensive and less based on the use of labor in the production process.

Table 7. FMOLS estimates in the long run (1984-2011)

\begin{tabular}{ll}
\hline Variable & Coefficient \\
\hline $\mathrm{C}$ & $2.16^{\mathrm{a}}$ \\
$\operatorname{LOG}(\mathrm{K})$ & $0.67^{\mathrm{a}}$ \\
$\operatorname{LOG}(\mathrm{L})$ & $0.57^{\mathrm{a}}$ \\
& $\mathrm{R}^{2}=97.4$ \\
& Durbin-Watson: 1.47 \\
\hline
\end{tabular}

Source: Table (A-2) in Appendix. a indicates significance at the $1 \%$ level.

The 0.67 estimate for $\alpha$ indicates that a 10 percent increase in the capital leads to a 6.7 percent increase in the 
output level, which implies there is diminishing returns to capital. Similarly, the 0.57 estimate for $\beta$ indicates that a 10 percent increase in the labor leads to a 5.7 percent increase in the output level, which implies there is diminishing returns to labor. However, the sum $\alpha+\beta=0.67+0.57=1.24$ is greater than one, which implies production exhibits "increasing returns to scale". Increasing returns to scale means a proportionate increase in all inputs leads to a more than proportional increase in the output. For example, doubling all inputs would lead to more than a doubling of output. In this case, $\alpha+\beta=1.24$ indicates a one hundred percent increase in (or doubling of) the inputs leads to a 124 percent increase in the output level.

\section{Concluding Remarks and Policy Implications}

This paper introduces an explanation of Saudi economic growth along the lines proposed by the neo-classical growth theory. Production function estimates for gross domestic product is provided using Cobb-Douglas function. A wide range of econometric testing is employed. The functional form is estimated using a constant to express the technical progress. The result shows an elasticity of output with respect to capital and labor of about 0.67 and 0.57 respectively. Technical progress has positive contribution to growth rate of output of $8.67 \%$ a year.

Production in Saudi Arabia exhibits "increasing returns to scale." Increasing returns to scale means a proportionate increase in all inputs leads to a more than proportional increase the output. Therefore, it is a difficult task for the policy makers to determine the best policies for the enhancement of capital and labor on economic growth. The major policy implications and recommendations from our analysis are that Saudi Arabia needs to improve the rate of return to education in order to raise the productivity of labor. That may be occurred by investing large amount of resources in increasing and improving educational attainment for men and women, and by increasing the training levels in industrial and services sectors.

\section{References}

Akaike, H. (1973). Information theory as an extension of the maximum likelihood principle. In B. N. Petrov \& F. Csaki (Eds.), Second international symposium on information theory (pp. 267-281). Akademiai Kiado, Budapest, Hungary.

Dickey, D., \& Fuller, W. (1979). Distributions of the Estimators for Autoregressive Time Series with a Unit Root. Journal of American Statistical Association, 74, 427-431.

Douglas, P. H. (1948). Are There Laws of Production? American Economic Review, 38(1), 1-41.

Douglas, P. H. (1934). The Theory of Wages. New York: Macmillan.

Hansen, B. E. (1992). Testing for Parameter Instability in Linear Models. Journal of Policy Modeling, 14(4), 517-533.

Philips, P. C. B., \& Hansen, B. E. (1990). Statistical Inference in Instrumental Variables Regression with I(1), Processes. Review of Economic Studies, 57, 99-125. http://dx.doi.org/10.2307/2297545

Phillips, P. C. B., \& Moon, H. R. (1999). Linear Regression Limit Theory for Nonstationary Panel Data. Econometrica, 67, 1057-1111. Retrieved from http://cowles.econ.yale.edu/P/cd/d12a/d1222.pdf

Saudi Arabian Monetary Agency (SAMA). Annual Report, No. 48. Retrieved from http://www.sama.gov.sa

World Bank, World Bank Development Indicator. Retrieved from http://data.worldbank.org/indicator/ 


\section{Appendix}

Table A1. Economic data (1984-2011)

\begin{tabular}{|c|c|c|c|}
\hline Period & $\begin{array}{l}\text { Real Gross Domestic Product (RGDP) } \\
(2005=100) \\
\text { (Billion Riyal) }\end{array}$ & $\begin{array}{l}\text { Real Gross Capital Formation (RI) } \\
(2005=100) \\
\text { (Billion Riyal) }\end{array}$ & $\begin{array}{l}\text { Number of Employees } \\
\text { (L) } \\
\text { (Million) }\end{array}$ \\
\hline 1984 & 443.27 & 112.89 & 3.55 \\
\hline 1985 & 408.93 & 92.10 & 3.85 \\
\hline 1986 & 361.62 & 82.47 & 4.11 \\
\hline 1987 & 365.81 & 82.57 & 4.39 \\
\hline 1988 & 368.01 & 71.43 & 4.63 \\
\hline 1989 & 395.94 & 75.04 & 4.87 \\
\hline 1990 & 476.47 & 92.18 & 5.05 \\
\hline 1991 & 511.95 & 106.09 & 5.14 \\
\hline 1992 & 529.78 & 109.85 & 5.24 \\
\hline 1993 & 507.80 & 113.79 & 5.40 \\
\hline 1994 & 514.45 & 96.70 & 5.59 \\
\hline 1995 & 521.54 & 102.44 & 5.77 \\
\hline 1996 & 569.97 & 100.74 & 5.96 \\
\hline 1997 & 596.01 & 106.95 & 6.18 \\
\hline 1998 & 527.24 & 110.98 & 6.40 \\
\hline 1999 & 591.53 & 117.71 & 6.67 \\
\hline 2000 & 702.06 & 124.22 & 6.90 \\
\hline 2001 & 691.78 & 128.44 & 7.18 \\
\hline 2002 & 711.04 & 130.15 & 7.48 \\
\hline 2003 & 804.78 & 149.63 & 7.74 \\
\hline 2004 & 936.45 & 157.44 & 8.01 \\
\hline 2005 & 1172.40 & 195.63 & 8.29 \\
\hline 2006 & 1295.95 & 228.03 & 8.57 \\
\hline 2007 & 1340.98 & 274.58 & 8.85 \\
\hline 2008 & 1492.63 & 298.69 & 9.09 \\
\hline 2009 & 1138.88 & 293.69 & 9.26 \\
\hline 2010 & 1422.83 & 328.31 & 9.56 \\
\hline 2011 & 1749.11 & 336.77 & 9.81 \\
\hline
\end{tabular}

Source: Saudi Arabian Monetary Agency (SAMA), Annual Report, No. 48. World Bank, World Bank Development Indicator.

Table A2. Fully modified ordinary least squares (fmols) regression results

Dependent Variable: LOG(RY)

Method: Fully Modified Least Squares (FMOLS)

Date: 03/18/13 Time: 19:48

Sample (adjusted): 19842011

Included observations: 28 after adjustments

Cointegrating equation deterministics: $\mathrm{C}$

Long-run covariance estimate (Bartlett kernel, Newey-West fixed bandwidth=4.0000)

\begin{tabular}{|c|c|c|c|c|}
\hline Variable & Coefficient & Std. Error & t-Statistic & Prob. \\
\hline LOG(RI) & 0.670715 & 0.062295 & 10.76671 & 0.0000 \\
\hline $\operatorname{LOG}(\mathrm{L})$ & 0.571598 & 0.099364 & 5.752579 & 0.0000 \\
\hline $\mathrm{C}$ & 2.163141 & 0.172901 & 12.51090 & 0.0000 \\
\hline R-squared & 0.973838 & Mean dependent var & \multicolumn{2}{|c|}{6.510146} \\
\hline Adjusted R-squared & 0.971745 & S.D. dependent var & \multicolumn{2}{|c|}{0.477476} \\
\hline S.E. of regression & 0.080260 & Sum squared resid & \multicolumn{2}{|c|}{0.161043} \\
\hline Durbin-Watson stat & 1.468732 & Long-run variance & \multicolumn{2}{|c|}{0.005634} \\
\hline
\end{tabular}

